\title{
Vozes da diversidade: um estudo sobre as experiências de inclusão de gestores e PcDs em cinco empresas paulistas
}

\author{
Voices of diversity: a study about the inclusion experiences of managers and \\ people with disabilities in five 'paulista' organizations
}

\author{
Janette Brunstein ${ }^{1}$ \\ Claudia Aparecida Serrano ${ }^{2}$
}

\begin{abstract}
Resumo
O objetivo nesta pesquisa é entender os significados atribuídos às experiências de inclusão de gestores e PcDs (Pessoas com Deficiência) a eles subordinadas nas relações de trabalho cotidianas em grandes organizações. Seguindo a proposta dos estudos qualitativos básicos ou genéricos de Merriam, conduziu-se um estudo em cinco empresas paulistas que adotam políticas formais de diversidade e inclusão: três instituições do setor financeiro (um banco nacional privado, um banco multinacional e um banco nacional público), uma empresa do mercado editorial e uma organização pública do setor de transporte. Embora os resultados apontem que, a despeito de todos os avanços, o discurso e a prática da inclusão nas organizações nem sempre conciliam o respeito à diferença com igualdade de oportunidades, e que as experiências se concentram no paradigma de suporte e serviços, muito mais do que no paradigma de empoderamento da $P c D$, o estudo contribui para o entendimento do que é inclusão e quais suas implicações para PcDs, gestores e para a própria organização.
\end{abstract}

Palavras-chave: diversidade, inclusão, pessoas com deficiência, organizações.

\section{Abstract}

The objective of this research is to understand the meaning related to the inclusion experiences of managers and their People with disabilities (PwD) subordinates within the everyday working relation at great organizations. Following the basic or generic qualitative studies by Merriam, an investigation was conducted at five 'Paulista' organizations which adopted formal diversity and inclusion policies: three from the financial sector (one Private National Bank, one Multinational Bank and a Public Bank), a publishing market company and a public organization of the transport sector. Although the results highlights that, in spite of all the advances, the discourse and the praxis of inclusion at great organizations do not always conciliate the respect to the difference with opportunity equalities, and that the experiences are concentrated in the paradigm of support and services, much more than the paradigm of empowerment of PwD, the study contributes to the understanding of what is inclusion and its implications for PwD, managers and even to the organization.

Keywords: diversity, inclusion, people with disabilities, organizations

\footnotetext{
Doutora em Educação pela Faculdade de Educação da Universidade de São Paulo (USP)Professora do programa de Pós-Graduação Stricto Sensu em Administração de Empresas da Universidade Presbiteriana Mackenzie. Endereço: Rua Aimberé, 1774 apto 41 - Perdizes -São Paulo/SP - Brasil - CEP: 01258020 Email: janette9@uol.com.br

${ }^{2}$ Mestre em Administração pela Universidade Presbiteriana Mackenzie (UPM). Consultora de Recursos Humanos - W. Alonso Consultores Associados Ltda.

Endereço: Alameda dos Arapanés 881 - Moema - São Paulo/SP - Brasil -CEP: 04524001. Email: claudia@walonso.com.br

Artigo submetido em janeiro de 2008 e aceito em março 2008
} 


\section{Introdução}

O significado da inclusão de pessoas com deficiência (PcDs) na organização, a partir de uma reflexão sobre as formas de enfrentamento das tensões entre eficiência/ deficiência e inclusão/exclusão com que se deparam PcDs e gestores em suas atividades práticas cotidianas em grandes empresas, é a temática central deste texto. Nesse sentido, é importante pontuar que o estudo aqui proposto insere-se no âmbito dos estudos de diversidade, já que se pretende lançar luz sobre o debate da seguinte questão: o discurso e a prática da inclusão nas organizações conciliam o respeito à diferença com igualdade de oportunidades?

O objetivo é entender os significados atribuídos às experiências de inclusão de gestores e PcDs que lhes são subordinadas, com a intenção de contribuir não só para o entendimento do que seja inclusão, mas também sobre as implicações destes significados para PcDs, gestores e a própria organização. Para tanto, propõe-se uma análise qualitativa, suportada pelo paradigma interpretativo, o qual privilegia a visão dos atores do processo, buscando extrair suas interpretações sobre a experiência que vivenciam nas organizações.

A contratação de pessoas com deficiência é uma resposta reativa das empresas à pressão de grupos sociais em situação de desvantagem, ao dispositivo legal que determina a lei de cotas e à crescente atenção dos consumidores às empresas socialmente responsáveis. Nesse sentido, a atenção à diversidade nas organizações emerge em situações de crise entre grupos ou conflito explícito (PFEFFER, 1985). Inclusão é, portanto, fruto de movimentos de pressão social (THOMAS; ELY, 1996; DASS; PARKER, 1999), o que faz com que sua prática no ambiente corporativo nem sempre reflita a qualidade semântica do termo.

É importante considerar que, neste estudo, parte-se do princípio de que deficiência é uma construção social. Sendo assim, rejeita-se o paradigma biológico, que se concentra nos aspectos corporais e congênitos envolvidos na deficiência, e valoriza-se a interpretação dos grupos sociais e o efeito do ambiente na concepção do que é deficiência (WOODHAMS; DANIELI, 2000).

Ferdman e Davidson (2002) afirmam que a inclusão deve ser feita em dois níveis: o individual e o grupal. Sendo um processo de mão dupla, a percepção da $\mathrm{PcD}$, das equipes de trabalho e da própria organização sobre o seu papel pode tornar o processo mais fácil ou mais dificil. Partindo dessa concepção, privilegiou-se neste estudo a perspectiva de PcDs e gestores e seus relatos de experiências como elementos-chave para tentar compreender o universo da inclusão empresarial. Os significados atribuídos pelos atores devem ser legitimados a ponto de se tornarem um sólido alicerce na construção de uma cultura inclusiva em todas as práticas organizacionais.

Analisar o universo da $\mathrm{PcD}$ em cinco empresas que apresentam estágios bem distintos de inclusão tem por pressuposto de que esta é conduzida de forma desigual nas organizações, seja pela qualidade das vagas ofertadas, seja pelas possibilidades de ascensão profissional. Não se pode ignorar o contexto organizacional no qual a inclusão está sendo analisada, dado que cada empresa possui regras próprias e dinâmicas específicas. Esta compreensão permite trabalhar a inclusão de forma mais coerente, envolvendo tanto os aspectos culturais (valores, atitudes, cognições e comportamentos), quanto sociais da organização (GLASTRA et. al., 2000).

Dessa forma, pergunta-se: o que é inclusão? Quais os pressupostos da organização sobre inclusão? Qual a concepção de inclusão dos gestores que trabalham com a PcD? Como estas percepções afetam as relações de trabalho e o desenvolvimento profissional da PcD?

Os estudos sobre a inclusão das PcDs no mercado de trabalho têm focalizado a dificuldade dessa inserção, apesar da política das cotas (NERI, 2003; JAIME; CARMO, 2005); das dificuldades percebidas pelas PcDs ao buscar uma colocação no mercado (BATISTA, 2004; CARVALHO-FREITAS; MARQUES; SCHERER, 2004; HEINSKI, 2004; JAIME; CARMO, 2005); da necessidade de adequação dos postos de trabalho; e da falta de preparo do mundo industrial para absorver estes profissionais (SILVA, 1993 apud CARVALHOFREITAS; MARQUES, 2006). A questão da interpretação compartilhada da deficiência foi analisada por meio de uma perspectiva histórica por Carvalho-Freitas e Marques (2006), que validaram dois instrumentos de 
avaliação da Gestão da Diversidade relativos à inserção das PcDs nas organizações - o Inventário de Concepções de Deficiência (ICD) e o Inventário de Condições e Procedimentos de Trabalho (ICPT).

Tais pesquisas apontam a presença de comportamentos contraditórios nas empresas em relação à inclusão da $\mathrm{PcD}$, que vão desde a segregação - caracterizada pela contratação dessas pessoas em categorias de trabalhos considerados 'menores', demonstrando uma eminente conduta discriminatória - até o reconhecimento do desempenho desses profissionais e suas possibilidades de progresso (BATISTA, 2004).

Para que se possa analisar a qualidade dos processos de inclusão, suas implicações nas relações de trabalho, nas formas como podem minimizar ou potencializar preconceitos e no desenvolvimento profissional da PcD, é preciso entender seu significado, a partir do estudo da experiência dos sujeitos que vivenciam o processo. É nesta direção que esta pesquisa pretende contribuir às já existentes. A compreensão do significado é de fundamental importância às empresas que desejam desenvolver práticas inclusivas que transcendam as prescrições de normas, práticas e procedimentos de treinamento que não garantem um processo pleno.

\section{Pressupostos teóricos}

\section{Diversidade nas organizações empresariais}

Embora a diversidade venha ganhando espaço no campo dos estudos organizacionais, seu conceito reflete falta de especificidade. As definições mais restritas enfatizam raça, etnia e gênero; as mais amplas estendem-se a idade, história pessoal e corporativa, formação educacional, função e personalidade (THOMAS, 1991 apud NKOMO; COX, 1999). Nkomo e Cox (1999) observam que o termo pode ser considerado incompleto, uma vez que pode levar a interpretações ambíguas, indicando a necessidade de se estruturar o próprio conceito: diversidade em quê? O que é diverso nas organizações? O que realmente está sendo estudado?

A diversidade refere-se a características humanas que diferenciam as pessoas umas das outras. A diversidade cultural está contida no conceito de diversidade, uma vez que se refere a um sistema social de pessoas pertencentes a afiliações grupais com significados culturais distintos (HANASHIRO, 2007).

Diversidade é "um misto de pessoas com identidades grupais diferentes dentro do mesmo sistema social" (NKOMO; COX, 1999, p. 335). Esta definição nos remete ao entendimento do conceito de identidade, para que o tema 'diversidade' nas organizações possa ser compreendido em sua plenitude, uma vez que os membros do grupo compartilham paradigmas e significados que determinam os limites do próprio grupo e permitem a interação e a compreensão entre eles (TORRES; PÉREZ-NEBRA, 2004).

A gestão da diversidade nas organizações requer mudanças culturais e não apenas em procedimentos administrativos. Para Cox (1991), um modelo de gestão da diversidade que traga benefícios implica administrar as relações de trabalho, a composição da força de trabalho e as práticas de emprego. Para capitalizar os benefícios e minimizar as despesas da diversidade, é preciso que as organizações tornem-se multiculturais, ou seja, estejam dispostas a utilizar e encorajar a diversidade cultural. A gestão da diversidade é necessária para que as pessoas possam usar plenamente seu potencial (THOMAS JR., 1996).

Linhas de pesquisa sugerem medidas para facilitar a utilização de diferenças entre grupos a serviço da organização, de seu crescimento e sua renovação; entre elas: (1) as lideranças devem reconhecer que, com a diversidade, existirá mais de uma maneira de se obter resultados positivos; (2) as lideranças devem estar comprometidas a preservar a expressão que diferentes formas perceptivas podem trazer à organização; (3) a cultura organizacional deve criar expectativas de alto padrão para todos, sem diferenciações; (4) a cultura organizacional deve estimular o desenvolvimento pessoal; (5) a cultura organizacional deve encorajar os debates e as controvérsias e dar suporte aos conflitos construtivos do trabalho; (6) a cultura organizacional deve fazer os trabalhadores se sentirem valorizados; (7) a organização deve ter uma missão articulada e amplamente 
divulgada; (8) a organização deve ter uma estrutura relativamente igualitária e não-burocrática (THOMAS; ELY, 1996, p. 85).

Fleury (2000) observa que o tema diversidade cultural é relativamente novo no Brasil, com objetos de discussão relacionados a negros, mulheres e homossexuais -, atinge, assim, mais a mídia e ecoa nas esferas comportamentais, mas gera poucas medidas concretas.

No que se refere às PcDs, o tema vem sendo explorado de maneira mais intensiva nos últimos dois anos, uma vez que até 2004 poucos artigos foram publicados (COSTA; FERREIRA, 2006), o que demonstra uma lacuna significativa a ser preenchida.

\section{A compreensão da deficiência}

A realidade da qual temos consciência e o conhecimento que temos dela são produtos da sociedade, que é construída pelo próprio indivíduo. A interação entre o indivíduo e o seu meio leva a que o primeiro influencie o segundo e, por este, seja moldado (BERGER; LUCKMANN, 2003). As interações sociais e o convívio pessoal são elementos essenciais da realidade da vida cotidiana, sendo esta realidade o agente que, com base nos referenciais comuns estabelecidos, permite um efetivo convívio e o estabelecimento de padrões comuns. Pessoas na organização produzem sentidos, e o ambiente é criado a partir da construção coletiva de significados e esta construção vai além da interpretação, uma vez que inclui a geração do que é interpretação (WEICK, 1995).

O conceito de deficiência é um modelo socialmente construído, existe somente dentro do ambiente social que desvaloriza o que não considera eficiente (WOODHAMS; DANIELI, 2000). No dicionário, a palavra 'deficiência' é remetida ao conceito de "falta, falha, carência, imperfeição, defeito, insuficiência" (FERREIRA, 1999 , p. 614). O sentido negativo da palavra "tem a ver com uma civilização cujo fundamento é a eficácia, a capacidade de produzir efeitos, e tudo é medido por essa capacidade" (D'AMARAL, 2004, p. 14). Neste sentido, o entendimento do processo histórico que produziu o significado da inclusão não pode ser ignorado (ARANHA, 2001; CARVALHO-FREITAS; MARQUES, 2006; SASSAKI, 2006).

Carvalho-Freitas e Marques (2006) realizaram um amplo levantamento histórico que auxilia no entendimento das formas de interpretação da deficiência ao longo do tempo. A matriz de interpretação a seguir, desenvolvida pelos autores, foi definida em função das modalidades predominantes que organizam a atividade social, favorecendo ou dificultando a inserção social das PcDs. Essas matrizes são formas de interpretação da deficiência ainda presentes na atualidade, pois implicam ações diversas que resultam em maior ou menor possibilidade de inclusão da $\mathrm{PcD}$ no trabalho.

\section{Quadro 1 - Síntese das principais concepções sobre deficiência}

\begin{tabular}{|c|c|c|}
\hline $\begin{array}{l}\text { Matriz de interpretação } \\
\text { predominante/contexto histórico de } \\
\text { origem e reedição }\end{array}$ & Ação social predominante & $\begin{array}{l}\text { Possibilidades de inserção da pessoa } \\
\text { com deficiência }\end{array}$ \\
\hline $\begin{array}{l}\text { Subsistência/sobrevivência (Grécia } \\
\text { Antiga; período pós } 2^{\mathrm{a}} \text { Guerra } \\
\text { Mundial; atualidade, de forma } \\
\text { implícita). }\end{array}$ & $\begin{array}{l}\text { Ações de exclusão ou inclusão social da } \\
\text { pessoa com deficiência com vistas a } \\
\text { propiciar a manutenção da sociedade. }\end{array}$ & $\begin{array}{l}\text { Integração mediante comprovação de } \\
\text { contribuição social efetiva, por meio do } \\
\text { trabalho. }\end{array}$ \\
\hline
\end{tabular}

Sociedade ideal e função instrumental

da pessoa (período clássico - séc. VI

a.C. ao ano 322 a.C.; $2^{\text {a }}$ Guerra

Exclusão social.

Ausência de possibilidade de integração.

Mundial; atualidade - grupos 
neonazistas).

Espiritual (Idade Média; atualidade). Segregação/caridade.

Segregação em instituições de caridade separadas da sociedade ou exposição pública sujeita à compaixão.

Segregação em instituições hospitalares

Normalidade (Idade Moderna; atualidade).

Segregação/integração.

Inclusão das pessoas com deficiência nos diversos espaços sociais.

Diversidade (Século XX).

Técnica (principalmente a partir de 1990).
Gestão da diversidade como recurso a ser administrado nas organizações de trabalho. ou psiquiátricas ou inserção da pessoa com deficiência mediante sua 'retificação' e adequação social.

Inclusão das pessoas com defíciência a partir de suas potencialidades.

Inclusão no trabalho e maior ou menor adaptação da pessoa com deficiência em função da forma como é gerida a diversidade nas organizações.

Fonte: Carvalho-Freitas e Marques (2006).

As concepções que a sociedade assume sobre o homem, sobre si própria e sobre a diferença determinarão as ações em relação à PcD, o que também ressalta os valores que as permeiam. Aranha (2001) destaca quatro paradigmas de tratamento para essas pessoas: 1) da institucionalização, caracterizado pela segregação de pessoas em instituições e escolas especiais; 2) de serviços, caracterizado pela disponibilização de serviços, em sua grande maioria, em ambientes segregados, para tornar a pessoa 'pronta' para sua integração na comunidade; 3) de suportes, com a disponibilização de todo e qualquer apoio necessário à otimização do potencial da $\mathrm{PcD}$, no que se refere à qualidade de vida e à real inclusão em todos os aspectos de sua vida; e 4) do empowerment, que visa a garantir ao 'deficiente' o poder decisório e o de determinar o encaminhamento de sua própria vida; assim tem a possibilidade de assumir o maior controle possível sobre a qualidade de sua vida.

Complementarmente, Sassaki (2006) observa que a prática da integração social ocorria e ainda ocorre sob três formas de inserção: a PcD consegue, por seus próprios méritos, utilizar espaços físicos e sociais, programas e serviços sem nenhuma modificação por parte da sociedade; a PcD necessita de alguma adaptação específica para conviver com pessoas 'não-deficientes'; e a PcD é inserida em ambientes segregados dos demais (classes especiais, setor separado na empresa, horários especiais em clubes etc.). No sistema integrativo, a 'inclusão' é unilateral, ficando por conta exclusiva de $\mathrm{acD}$ adaptar-se ao contexto e às condições existentes.

Concepções sobre as dificuldades dos trabalhadores com deficiência como decorrência de suas próprias condições orgânicas reforçam as dificuldades de contratação (TANAKA; MANZINI, 2005). Crenças que geram expectativas negativas a respeito dessas pessoas quanto ao alto absenteísmo, produtividade de baixa qualidade, grandes gastos para adaptar o local de trabalho e à baixa aceitabilidade por parte dos outros colegas de trabalho são aspectos que reforçam essa dificuldade (FREEDMAN; KELLER, 1981).

Esta concepção sobre a deficiência retrata a maior dificuldade para a inclusão plena - a visão fragmentada sobre a PcD associada à falta de informação. Além do desconhecimento sobre as reais capacidades e limitações do 'deficiente', a desinformação gera também o desconhecimento de suas potencialidades, necessidades, expectativas e sentimentos, o que contribui para conservar os preconceitos sobre esta população.

A compreensão do significado da inclusão e suas ações conseqüentes pressupõem um processo bidirecional, envolvendo aquele que inclui e aquele que é incluído. Não basta estar dentro de uma empresa ou outros espaços públicos para estar incluso, já que os princípios da exclusão estão incutidos nas relações (QUINTÃO, 2005). 


\section{Inclusão e redes de relacionamento}

A inclusão da PcD pressupõe acessibilidade em diversos níveis: arquitetônica (eliminação de barreiras físicas), comunicacional (eliminação de barreiras de comunicação interpessoal), metodológica (eliminação de barreiras nos métodos de estudo, trabalho etc.), instrumental (eliminação de barreiras nos instrumentos e ferramentas de trabalho), programática (referente a políticas públicas, normas e regulamentos) e de atitude (preconceitos, estigmas, discriminação) (SASSAKI, 2006). A inclusão acontece em dois níveis, no individual e no organizacional, sendo criada em cada momento e em cada interação (FERDMAN; DAVIDSON, 2002).

Sendo o homem um ser social, possui interfaces que tanto o separam como o aproximam dos demais. O grupo é a base para a formação da identidade social, juntamente com as crenças e os comportamentos a ela associados. Esta identidade faz parte do autoconceito do indivíduo, que deriva do reconhecimento de pertencer a um grupo social, associado ao significado emocional e de valor ligado àquela filiação. É um processo social dinâmico, que se constrói por semelhança e oposição. Os indivíduos vêem a si mesmos como semelhantes aos membros do intragrupo (ou estes como semelhantes a si próprios) e como diferentes dos membros do extragrupo (TAJFEL, 1972 apud HOOG; TERRY, 2000).

A categorização das pessoas em grupos resulta em relações intergrupais que, por sua vez, definem os comportamentos sociais (HOGG; TERRY, 2000). A categorização social é o primeiro passo para o preconceito, que está presente em todas as instâncias e, em algum grau, em todas as pessoas (ARONSON; WILSON; AKERT, 2002). A manifestação do preconceito é individual, mas surge do processo de socialização como resposta aos conflitos gerados neste processo. O preconceito é, a priori, uma reação congelada, que pode assumir exagero de aceitação; pode levar-nos a dar um consolo antecipado a quem não o solicitou ou manifestar compaixão para esconder a aflição; ou aparecer em forma de rejeição (CROCHIK, 1995).

Goffman (1975) alerta para o fato de que, em uma interação, a observação da conduta e da aparência dá indícios que permitem às pessoas utilizar sua experiência anterior e aplicar estereótipos não-comprovados, em uma relação sutil, na qual as pessoas assumem e designam papéis umas às outras, em conformidade com o que é esperado, sem apresentar manifestações autênticas.

No caso das PcDs, se poderia considerar, por exemplo, que todas essas pessoas têm capacidades limitadas, o que justificaria sua contratação em posições inferiores. Tal visão revelaria uma expectativa de desempenho inferior por parte das chefias ou colegas de trabalho, bem como se refletiria na forma de relacionamento entre todos (CARVALHO-FREITAS; MARQUES, 2006). Nesse sentido, o indivíduo estigmatizado pode sentir-se inseguro quanto à reação das pessoas que o receberão em um novo contexto, como o identificarão, em qual categoria será colocado e se esta lhe será favorável ou não (GOFFMAN, 1988).

Cabe ressaltar que a percepção de estereótipo e discriminação pode estar apenas presente na $\mathrm{PcD}$, em função de sua biografia e suas representações mentais, que podem ser resultado de uma baixa auto-estima, levando a pessoa a responder a essa percepção de maneira defensiva. Aceitar a própria deficiência é o primeiro passo para a inclusão.

Para Goffman (1975, p. 21), quando um indivíduo projeta uma definição da situação de contato inicial, "e com isso pretende, implícita ou explicitamente, ser uma pessoa de determinado tipo, automaticamente exerce uma exigência moral sobre os outros, obrigando-os a valorizá-lo e tratá-lo de acordo com o que as pessoas de seu tipo têm o direito de esperar". Uma pessoa estigmatizada pode dedicar um grande esforço individual no domínio de atividades consideradas geralmente 'fechadas' - por motivos físicos ou circunstanciais - a pessoas como ela, numa tentativa de romper com a realidade de seus atributos, empregando uma interpretação nãoconvencional do caráter de sua identidade social.

Quanto mais freqüentes as interações, mais provável que relações e comportamentos sociais se desenvolvam paralelamente às relações e aos comportamentos de trabalho. As pessoas tenderão a se aproximar daquelas que consideram mais parecidas consigo e evitar as que não atendam a esse critério. Contudo, sentimentos negativos 
podem ser muitas vezes superados quando há interação de fato e, com isso, passa-se a conhecer uma pessoa ou um grupo em particular.

As pessoas reagem ao desconhecido, e passar a conhecê-lo é uma forma de reconstruir significados. Assim, sendo o preconceito o resultado de uma cognição social, uma das formas de reduzi-lo seria reunir os grupos intra e extra, ou seja, propiciar o contato entre as pessoas.

A teoria da hipótese do contato, desenvolvida por Allport (1954 apud ARONSON; WILSON; AKERT, 2002), surge do pressuposto da atração interpessoal, ou seja, o contato entre membros de grupos distintos permitiria verificar as semelhanças existentes quanto a valores, idéias, emoções e, assim, reelaborar a percepção inicial de diferenças. Essa hipótese implica que o preconceito é um julgamento estabelecido na ausência da experiência. Contudo, Allport não se refere ao simples contato. Para o autor, ele tem de ser feito entre pessoas em uma relação de interdependência na busca de objetivos comuns.

Assim, freqüência, diversidade, duração, o estatuto dos grupos dos membros em relação - se de caráter competitivo ou cooperativo, se de dominação ou de igualdade, se voluntário, se real ou artificial -, o tipo de personalidade dos indivíduos e as áreas do contato são fundamentais para a redução do preconceito. Condições inadequadas podem levar a efeitos negativos.

\section{Procedimentos de investigação e análise}

Este estudo é de natureza qualitativa e baseado no paradigma interpretativista (GUBA; LINCON, 2000; GEPHART, 2004), já que a pretensão foi interpretar e discutir as múltiplas visões de mundo e significados atribuídos pelos sujeitos da pesquisa às suas experiências de inclusão. $\mathrm{O}$ interesse do pesquisador é buscar o sentido e as contradições dos discursos, presentes nas falas de gestores e PcDs subordinadas, observando de que forma revelam estruturas de inclusão e exclusão.

A orientação metodológica seguiu a proposta do estudo qualitativo interpretativo básico ou genérico proposto por Merriam (1998) e Caelli e Ray e Mill (2003), que entendem a propriedade do método, no caso de pesquisas, cujo foco não é a cultura (como na pesquisa etnográfica) nem a análise de uma unidade em particular, como propõe o estudo de caso. Concentra-se este tipo de estudo na perspectiva e visão de mundo das pessoas envolvidas no contexto investigado. Isso significa que a análise do discurso dos gerentes e seus PcDs subordinados foi feita à luz da natureza da empresa onde os atores da pesquisa foram entrevistados, bem como do contexto das políticas de diversidade e inclusão que adota cada organização.

Para a construção dos dados, recorreu-se à técnica da entrevista em profundidade, semi-estruturada. Seu uso seguiu os pressupostos contemporâneos que apontam para a necessidade de pensar a entrevista como um evento interativo, dialógico; enfim, uma co-produção entre entrevistador e entrevistado, como pregam Chambon (1995), Mason (2002) e Bryman (2004).

Os achados de pesquisa são um misto de descrição e análise. Merriam (2002) aponta que o estudo qualitativo interpretativo básico ou genérico está interessado em investigar: a) como as pessoas interpretam suas experiências, b) como as pessoas constroem seu mundo, e c) que significados as pessoas atribuem a esta experiência.

Tomando como objeto de estudo as experiências de inclusão de PcDs, foram selecionadas cinco empresas que têm programas formais de diversidade e inclusão. Três pertencem ao setor financeiro (um banco nacional privado, um multinacional e um nacional público) e estão em diferentes estágios quanto às suas políticas inclusivas. A pesquisa contou ainda com uma empresa do mercado editorial e uma organização pública do setor de transporte. Foram dois os critérios para seleção da empresa: sua natureza pública e privada, nacional e multinacional, e o tempo de implantação dos programas de diversidade/inclusão, que não poderia ser inferior a dois anos. 
Nestas empresas, foram entrevistados sete gestores e sete PcDs a eles subordinadas, havendo variação da idade, tempo de empresa, cargo, tipo e grau de deficiência. Os principais eixos das entrevistas com os gestores foram: histórico e processo de inclusão; papel do gestor; suporte organizacional; política de diversidade/inclusão; e conceitos de inclusão e aprendizagem. Nas entrevistas com as PcDs, destacaram-se os seguintes pontos: histórico da qualificação profissional; trajetória profissional na organização; barreiras e estratégias de enfrentamento; política de diversidade/inclusão; percepção dos pares e rede de relações; sentimento e idéia de inclusão; e aprendizagem.

Além das entrevistas, foram analisados materiais institucionais que descrevem a política formal de diversidade e inclusão.

O tratamento dos dados coletados foi conduzido seguindo a proposta de Flores (1994) sobre interpretação do conteúdo da informação textual. Para analisar, interpretar e categorizar as informações obtidas, os dados apreendidos por meio das entrevistas em profundidade foram exaustivamente manipulados na busca de padrões, coerências e núcleos centrais de significados. O processo de categorização foi conduzido a posteriori. Definiram-se, assim, cinco conjuntos de categorias centrais (metacategorias) e seus elementos pertinentes, buscando, ao final, entender de que forma estas se inter-relacionam. A descrição deste processo está detalhada no item de análise dos dados.

Como método de validação das análises e do processo de categorização, recorreu-se à técnica de comparação dos resultados obtidos por outros investigadores especialistas (MERRIAN, 1998). Assim, o conjunto de informações foi analisado por dois especialistas: um em inclusão de PcDs e outro em diversidade nas organizações.

\section{Apresentação e análise dos resultados}

\section{O perfil dos entrevistados e os programas de diversidade/inclusão das empresas objeto de estudo}

A seguir apresenta-se um quadro-síntese que resume a política de diversidade/inclusão das empresas objetos de estudo e o perfil dos entrevistados.

\section{Quadro 2 -Caracterização dos entrevistados.}

\begin{tabular}{|c|c|c|}
\hline & Política de diversidade/inclusão & Perfil dos entrevistados \\
\hline $\begin{array}{l}\text { Empresa } 1 \\
\text { Banco público }\end{array}$ & $\begin{array}{l}\text { Sua missão contempla a melhoria } \\
\text { da qualidade de vida da sociedade } \\
\text { e o desenvolvimento urbano e } \\
\text { social. } \\
\text { Desenvolve ações de } \\
\text { conscientização dos empregados } \\
\text { sobre a importância da } \\
\text { responsabilidade social, com } \\
\text { destaque em seu planejamento } \\
\text { estratégico para a elaboração de } \\
\text { uma política de valorização da } \\
\text { diversidade. } \\
\text { Processo ainda em fase de } \\
\text { consultoria. } \\
\text { Ações emergenciais priorizadas: } \\
\text { treinamento em libras (língua } \\
\text { brasileira de sinais) de, pelo } \\
\text { menos, um funcionário em cada } \\
\text { agência em Libras (Língua }\end{array}$ & 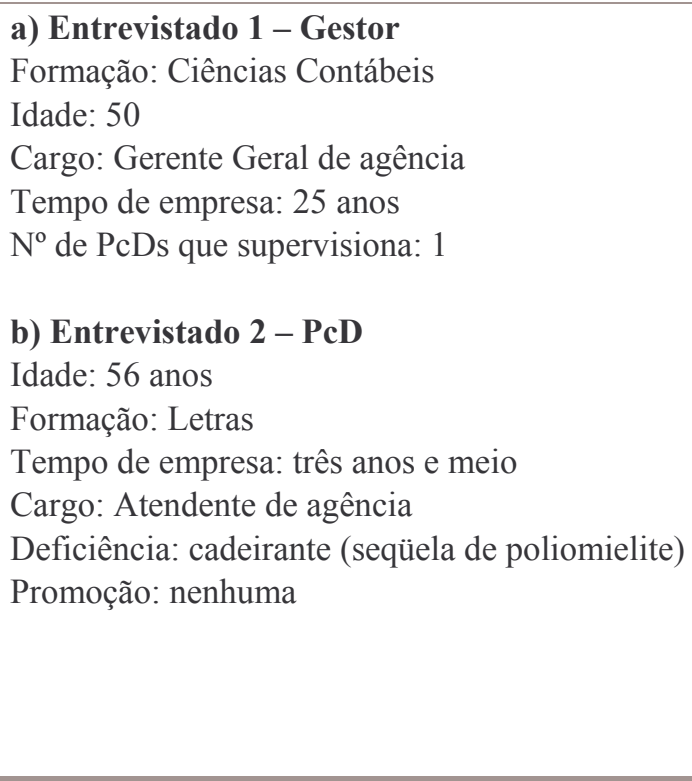 \\
\hline
\end{tabular}


Brasileira de Sinais); treinamento

de funcionários para atender PcDs

nas agências.

Declara, em sua missão, valores associados à responsabilidade social e sustentabilidade.

Possui comitês e comissão para tratar de assuntos voltados à responsabilidade social e diversidade corporativa.

Nos comitês de diversidade, PcDs se reúnem periodicamente com a intenção de melhorar suas

Empresa 2

Banco privado nacional condições na organização quanto a:

- acessibilidade;

- transporte;

- aparelhos específicos;

- problemas enfrentados;

- sugestões.

\section{a) Entrevistado 1 - Gestor}

Cargo: Gerente Geral de agência

Idade: 40

Formação: Ciências Contábeis

Tempo de empresa: sete anos

$\mathrm{N}^{\mathrm{o}}$ de PcDs que supervisiona: 1

\section{b) Entrevistado 2 - PcD}

Idade: 22 anos

Formação: Propaganda e Marketing

Tempo de empresa: dois anos

Cargo: Analista Júnior

Promoção: de Contínuo (Auxiliar Administrativo) a Analista Júnior da área de Gerência de Cadastro e Comissão de Fundos Deficiência: congênita do membro superior (pessoa sem uma das mãos)

\section{c) Entrevistado 3 - PcD}

Idade: 27 anos

Formação: cursa atualmente a faculdade de Gestão de Negócios Tempo de empresa: três anos e meio

Cargo: Contínuo (Auxiliar Administrativo)

Deficiência: visual parcial

Declara como missão valores associados à justiça social. da estratégia de sustentabilidade nos negócios.

Comitê de diversidade.

Palestras sobre o tema.

Materiais instrucionais sobre diversidade.

Acompanhamento dos processos de seleção e recrutamento de novos funcionários.

\section{Empresa 3}

Banco privado multinacional ambiente físico à acessibilidade. Entende diversidade como parte

\section{a) Entrevistado 1 - Gestor}

Cargo: Gerente Geral de agência

Formação: Administração de Empresas

Tempo de empresa: 13 anos

Gerencia uma equipe composta por 15 funcionários

Duas experiências em supervisionar funcionários com deficiência nos membros inferiores

\section{b) Entrevistado 2 - Gestor}

Cargo: Gerente Geral da agência

Formação: Administração de Empresas

Tempo de empresa: 22 anos

Gerencia uma equipe com 18 profissionais e já supervisionou quatro funcionários com deficiência nos membros inferiores e superiores Formação de grupos de suporte como: afro-descentes, mulheres, homossexuais e deficientes. Plano de saúde para parceiros do mesmo sexo.

\section{c) Entrevistada 3 - PcD}

Idade: 35 anos

Cargo: Subgerente

Promoção: depois de seis meses na empresa, passou de Escriturária a Subgerente,

Deficiência: adquiriu a deficiência aos três anos de idade, em conseqüência de uma paralisia infantil; caminha lentamente com a ajuda de um aparelho na perna e uma bengala.

Formação: atualmente cursa o segundo semestre de graduação em Administração de Empresas 


\section{Empresa 4}

Empresa do segmento editorial

\section{Empresa 5}

Empresa pública do segmento de transportes

\section{d) Entrevistada 4 - PcD}

Idade: 25 anos

Cargo: Subgerente

Formação: atualmente cursa o sexto semestre do curso de Administração.

Deficiência: aos quatorze anos de idade, em função de um acidente de carro, perdeu o movimento da perna direita e não tem articulação no joelho.

Tempo de empresa: um ano.

Promoção: indicado à promoção para o cargo de gerente
Desde 2001, estabelece como premissa criar uma cultura organizacional inclusiva. Preparação da área de recursos humanos, gestores e funcionários para a inclusão da PcD.

Tem por premissa reconhecer as potencialidades da $\mathrm{PcD}$ e desenvolvê-las.

Garantir autonomia social da PcD pela convivência com os demais membros da organização.

Desenvolve dinâmicas de grupo, workshops, feiras e eventos internos sobre o tema.

Adaptação das instalações.

Processo de recrutamento e seleção de PcDs diferenciados. Empregabilidade de PcD aparece como estratégia de sustentabilidade da empresa. Plano de retenção de talentos para PcDs.

\section{a) Entrevistado 1 - Gestor}

Cargo: Chefe de Departamento de Recursos Humanos e responsável pelo Programa de Inclusão

Formação: Assistência Social

Tempo de empresa: 17 anos, sendo os últimos 6 no Programa de Inclusão

\section{b) Entrevistado 2 - Gestor}

Cargo: Supervisor de Logística

Formação: Engenharia e Administração

Supervisiona oito PcDs auditivos

Tempo de empresa: oito anos

\section{c) Entrevistado 3-PcD}

Deficiência: aos três anos teve distemia, e, como conseqüência, fala com dificuldade e tem imobilidade parcial das mãos Escolaridade: ensino médio completo

Função: Auxiliar de Estoque

Tempo de empresa: nove meses

Promoção: nenhuma
Conta com 7.500 funcionários, dos quais 130 são $\mathrm{PcDs}$ (com tetraplegia, amputação, cadeirantes, com deficiência visual parcial e deficiência auditiva).

O Projeto de Inclusão de PcDs envolve um conjunto de ações como: projeto de educação para o trabalho, que atende a adolescentes com dificuldades de inserção no mercado de trabalho; um programa de readaptação para pessoas que, após algum evento, ficaram com algum tipo de incapacidade; e a contratação direta de pessoas com deficiência. Procura desenvolver ações mais amplas, como a contratação de estagiários com deficiência,

\section{a) Entrevistado 1 - Gestor}

Chefe do Departamento de Desenvolvimento Humano, responsável pelo Programa de Inclusão

Idade: 47 anos

Formação: Mestrado em Comunicação para o Mercado e graduação em Relações Públicas e Jornalismo.

Tempo de empresa: cinco anos.

\section{b) Entrevistado 2 - Gestor}

Formação: Coordenador de Estudos Econômicos Idade: 47 anos

Formação: Economia

Gerencia uma equipe composta por sete pessoas e, desde junho de 2005, tem na equipe um Analista Trainee tetraplégico, sendo esta sua primeira experiência em trabalho com uma PcD.

\section{c) Entrevistado 3 - PcD}

Deficiência: tetraplegia total Cargo: Analista Administrativo II 


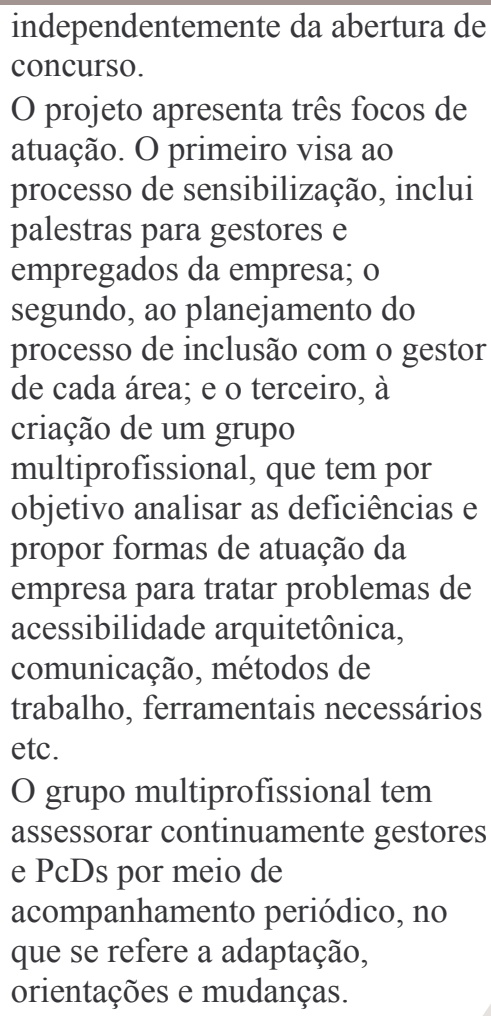

\section{Idade: 43 anos \\ Escolaridade: formação superior em Matemática. \\ Tempo de empresa: 20 anos}

Promoção: inicialmente na área de projetos ligados às comunicações e controle viário, participando do desenvolvimento à implantação do projeto. Aos cinco anos de empresa, sofreu um assalto e foi baleado na coluna na altura do pescoço, o que resultou em tetraplegia total. Após três anos de afastamento, foi reintegrado ao quadro funcional da companhia. Permaneceu por três anos na área de origem - Projetos -, porém sem poder desenvolver as atividades de campo que a função exigia, o que representou uma grande limitação em termos de atuação profissional. Depois deste período, foi transferido para outra área semelhante, com atuação no prédio administrativo, o que lhe conferiu maior autonomia , cuidando da manutenção dos equipamentos e fazendo projetos de ampliações e modificações de equipamentos e instalações.

Hoje integra a equipe multiprofissional da Gerência de Recursos Humanos (GRH), que cuida do processo de inclusão das PcDs, desenvolvendo atividades que vão desde a adequação do edital de contratação até a análise de todas as questões de acessibilidade ao trabalho e o acompanhamento do processo junto aos gestores e às PcDs.

Fonte: as autoras.

Foi possível extrair algumas considerações importantes do estudo das políticas empresarias de diversidade e seus respectivos programas de inclusão. Somente duas empresas (3 e 5) apresentaram políticas inclusivas mais abrangentes, destacando-se das propostas consideradas default. Na empresa 3, banco privado multinacional, a inclusão faz parte de uma ampla política de diversidade, que tem por base a formação de grupos de suporte (KAHNWEILER; RIORDAN, 1998), o que permite que os deficientes tenham possibilidade de se reunir periodicamente para discutir sua condição na organização e desenhar estratégias de ação que possam minimizar preconceitos e alavancar suas carreiras.

Tivemos a vitória de formar o grupo. Não foi fácil. As pessoas se questionavam: "Já não estão contratando? Pra que grupo? Entendeu? Pra quê?" Então, eu acho que a melhor vitória do grupo de deficiência pra pessoa com diversidade foi a formação dele. (PcD com seqüela de poliomielite, banco privado multinacional)

Na empresa 5, do setor de transporte, além de se contar com uma equipe multidisciplinar, buscou-se construir um programa de inclusão com base no entendimento sobre como um profissional com uma determinada deficiência trabalha. Isso se fez por meio de visitas a empresas que já contratavam deficientes, com o intuito de conhecer a natureza e especificidade de cada condição e criar um programa com identidade própria. Além disso, procurou-se envolver o próprio deficiente na coordenação das políticas inclusivas:

(...) A gente foi à Serasa não para ver um programa da Serasa: isso não nos interessava. A gente foi à Serasa para ver como é que o 'cara' da área financeira, que é tetraplégico, trabalha, com que equipamentos ele trabalha (...). Não interessa para a gente ver programas abrangentes, isso não é o nosso foco, disso a gente já tem bastante informação. O que a gente está fazendo agora é mergulhar 
nas especificidades, entender mais, entrar na minúcia da atividade (...), porque o 'genericão' não vai resolver. (Gestora responsável pela implantação do Programa de Inclusão)

Embora tais esforços ainda se mostrem insuficientes, como se poderá observar no decorrer do trabalho, avançam um pouco mais em relação aos demais casos analisados. No sentido oposto, a experiência mais drástica se observou na empresa 4 (segmento editorial). Como resposta à exigência legal, esta organização recrutou, sem estar preparada, $90 \%$ de pessoas com deficiência auditiva, em áreas operacionais. Uma vez que não conseguiam se fazer entender, ou serem entendidos, os deficientes se isolaram em grupos, o que levou, inclusive, a brigas internas com os pares sem deficiência, acarretando uma série de prejuízos e problemas. Sem especialização em libras, o suporte organizacional limitou-se à contratação de intérpretes. Mesmo com um alto contingente de trabalhadores surdos, ninguém na organização se apropriou da linguagem de sinais. Isso mostra a diferença entre uma política de diversidade/inclusão apenas esposada e uma política de fato introjetada na cultura organizacional.

É importante considerar ainda que, das sete PcDs entrevistadas, apenas uma possuía deficiência grave (tetraplegia), adquirida após anos de trabalho na organização.

\section{Estrutura dos discursos de PcDs e gestores sobre suas experiências de inclusão}

O processo de segmentação, redução e comparação dos dados que emergiram nas entrevistas permitiu analisar as estruturas discursivas de gestores e PcDs sobre suas experiências de inclusão baseando-se em cinco categorias centrais ou metacategorias: 1) significados e sentimentos da inclusão/exclusão; 2) política de diversidade/inclusão; 3) desenvolvimento profissional da PcD; 4) relações de trabalho; 5) aprendizagem e papel do gestor. Em cada uma dessas categorias, identificou-se um conjunto de subcategorias e seus elementos pertinentes.

\section{Figura 1 - Categorias centrais e subcategorias identificadas nas entrevistas.}

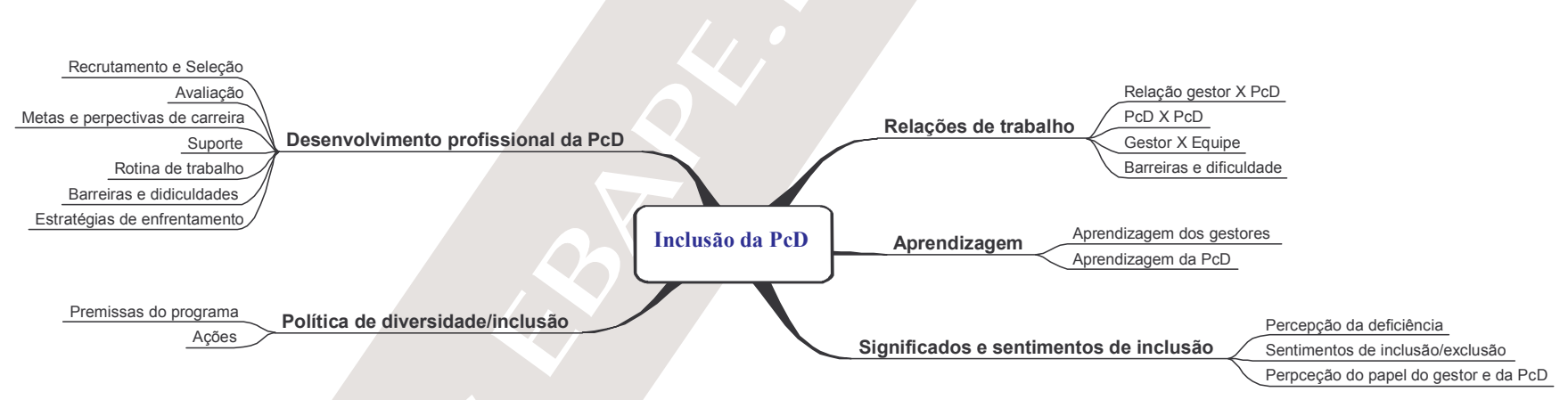

Fonte: as autoras.

Nesta fase de análise, superpõe-se em cada uma das categorias o que é essencialmente similar nos discursos, com idéias que exprimem percepções diferenciadas dos atores envolvidos. É importante esclarecer, ainda, que as falas consideradas representativas do pensamento dos entrevistados e que foram selecionadas para inclusão neste relatório foram agrupadas independentemente da empresa a qual os depoentes pertencem.

\section{O discurso de gestores e PcDs sobre o significado e sentimentos de inclusão/exc/usão}

- O que é inclusão?

O significado da inclusão é uma categoria que explica os pressupostos que estão por trás das ações e condutas dos atores do processo inclusivo. Três eixos no discurso dos gestores se sobressaíram quando indagados sobre a questão. No primeiro, denota-se inclusão como dar oportunidade, corrigir uma falha da sociedade, um ato de responsabilidade social. 
Inclusão é uma responsabilidade social. (Gestor 1, empresa do segmento editorial)

Oportunidade... incluir é como uma oportunidade. 'Inclusão' é a combinação de oportunidade juntamente com a vontade da PcD de ser um profissional melhor, [que] tem que buscar conhecimento. (Gestor 2, banco privado multinacional)

[...] É a correção de uma falha da sociedade que vem [culminando] há muito tempo. (Gestor 1, banco privado multinacional)

No segundo, inclusão aparece nos discursos vinculada à idéia de direito, respeito e igualdade:

[...] Pelo menos, nas apostilas que eu li, o meu entendimento de inclusão é você dar o direito [...] ou seja, igualdade das pessoas que são portadoras de deficiência de estar trabalhando dentro da empresa e você estar dando condições para que aquela pessoa possa se desenvolver. (Gestor, banco público)

[...] Inclusão pra mim é ter os mesmos direitos, as mesmas obrigações, desempenhar as mesmas funções que os funcionários sem necessidades especiais. Isso é inclusão. Não é tratar diferente. (Gestor 2, banco privado)

Em terceiro lugar, inclusão aparece associada à idéia de emancipação, o que significa olhar para a eficiência e a capacidade de desenvolvimento da PcD:

Nós definimos inclusão pela eficiência e não pela deficiência. Nós respeitamos a deficiência, reconhecemos, criamos condições pra que, dentro dessas deficiências, as pessoas se tornem eficientes e produtivas. Inclusão é você criar condições pra que as pessoas possam se desenvolver, possam ser produtivas e, em função dessa produtividade, ser independentes e decidirem sua vida. (Gestor 2, empresa do segmento editorial)

O discurso dos gestores transita entre a idéia de 'concessão' (corrigir falhas sociais) e de 'direito' (justiça social) e a noção de empoderamento (criar condições para o desenvolvimento da $\mathrm{PcD}$ ).

Enquanto os termos 'direito', 'justiça' e 'igualdade' predominam nas falas de gestores, termos como 'vida', 'ter espaço' e 'estar de fato' sintetizam a percepção das PcDs.

Incluir não é só você pegar aquela pessoa dentro da casa dela e colocar dentro da organização. Você tem que fazer com que essa pessoa acredite que realmente ela pode ter vida fora da casa dela, ou fora do hospital. Eu acho que esse que é o significado de inclusão. Inclusão é você mostrar para essa pessoa que existe vida. (Pessoa com deficiência no membro inferior direito, banco privado multinacional)

Inclusão pra mim é ter um espaço como qualquer outra pessoa. (Pessoa com seqüela de poliomielite, banco privado multinacional).

Eu acho que para o significado de inclusão [...] tem um termo que eu ouvi uma vez que eu sempre repito "Vida boa é vida vivida". Então acho que inclusão no trabalho é o sujeito estar lá de fato, fazendo algo que ele consegue e que é importante para a empresa e que lhe traga satisfação. Acho que isso é inclusão, estar lá de fato, com todos os recursos, a empresa disponibilizar isso e ele também conseguir dar esse resultado. (Pessoa com tetraplegia, empresa do segmento de transporte).

O discurso é mediado pelo sentimento de pertencimento. Significa que a PcD se percebe incluída, parte integrada do processo e que acredita ser capaz de dar resultados para a organização. 
Embora a noção de empoderamento tenha surgido em uma das falas dos entrevistados, nos discursos não está presente a idéia de inclusão associada à posição hierárquica da PcD na organização. Nesse sentido, questões de poder que discutem em que lugar os deficientes estão trabalhando na organização, e que é um indicador do grau de inclusão organizacional, não foram mencionadas em nenhuma das cinco empresas entrevistadas, nem por PcDs, nem por gestores, independentemente do avanço das políticas de diversidade/inclusão dessas corporações.

- Sentimento de inclusão/exclusão da PcD

Como se pode avaliar a inclusão? A condição em que vivem as PcDs no dia-a-dia das organizações, em que postos estão e o quanto se sentem incluídas serão sempre os indicadores da qualidade da inclusão. Nesta subcategoria os termos 'participar', 'ser solicitado' e 'ser cobrado como qualquer outro funcionário' são recorrentes nas falas dos entrevistados.

[...] Olha, eu me sinto incluida quando eu participo, quando minha equipe me solicita. Em uma reunião, se eu participo, eu me sinto incluida. Lá na rede, quando tinha alguma coisa e o gerente fazia questão que eu fosse, eu me sentia muito bem. Não importa a função: eu estava incluída. (Pessoa com seqüela de poliomielite, banco privado multinacional)

Quando eu circulo, eu tenho bons amigos dentro da empresa, em todo lugar, e as pessoas me recebem bem, tratam bem, procuram auxilio quando precisam, para as coisas mais diferentes, não é só naquilo que sou especialista, mas naquilo que acreditam que eu possa ajudar. Tem um tratamento de igual pra igual. Até quando eu tomo bronca, tem um tratamento de igual pra igual. (Pessoa com tetraplegia, empresa do segmento de transporte).

Eu sou cobrada, sou muito cobrada! Mas tem que ser cobrado, porque eu sou uma funcionária como outra qualquer. Eu acho que o tratamento deve ser igual, igual, igualzinho. (Pessoa com seqüela de poliomielite, do banco público)

O fato de ser solicitado, cobrado, é um indicador da crença dos pares no potencial da PcD. A inclusão propriamente dita engloba tanto os aspectos profissionais (contratação, oportunidades de desenvolvimento e o progresso na empresa) quanto os sociais (fazer parte do grupo).

De forma oposta, a descrença manifesta em relação à $\mathrm{PcD}$ é um indicador de exclusão, como se observa no relato abaixo:

Tinha um coordenador que sempre me dizia assim: "Olha, é uma tentativa da área, não significa que você vai estar aqui, a empresa pode achar outra posição para você, outro local para você trabalha". Ele saiu antes do que eu, ele 'jogou a toalha' primeiro. (Pessoa com tetraplegia, empresa do segmento de transporte)

Me sinto excluido quando tem um trabalho para ser feito, só que você fica ali de lado porque você tem uma deficiência. Eu sei que tenho capacidade de colaborar mais, só que fico restrito àquele local. (Pessoa com deficiência visual, banco privado)

Aqui se verifica a questão da aplicação do estereótipo não-comprovado a que se refere Goffman (1975), limitando a possibilidade do contato como redutor do preconceito (ALLPORT, 1954 apud ARONSON; WILSON; AKERT, 2002), uma vez que a PcD é colocada num status inferior.

- Percepção da deficiência

Uma subcategoria que ajuda a entender o significado da inclusão é a percepção do que é a deficiência para gestores e PcDs. Em nenhum momento definiu-se deficiência com um conceito ou idéia clara. As falas evidenciam o potencial cognitivo, intelectual e estratégico da $\mathrm{PcD}$, que se sobrepõe a qualquer limitação física. 
A contribuição que eu dou é efetivamente intelectual, é na minha posição de analista. O quanto eu sou rápido com o queixo deixou de ser importante. Eu consigo contribuir com as estratégias, com as informações, com a minha qualidade técnica, e isso deixa você valorizado. (Pessoa com tetraplegia, empresa do segmento de transporte)

No início, eu acho que tinha um questionamento maior das áreas com relação a ter plenitude da aptidão, da capacidade fisica, eu não diria nem intelectual, mas a capacidade fisica como um paradigma para trabalhar na área. Isso era um discurso recorrente, que eu não tenho ouvido mais. (Gestor, empresa do segmento de transporte).

Contudo, nos discursos podem-se observar, por vezes, contradições, como no caso abaixo:

A gente define as metas, orienta as pessoas, ensina diversas vezes. Existem pessoas portadoras de deficiência que têm uma facilidade muito maior de aprender do que pessoas que, teoricamente, têm todos os sensores funcionando. Ele [referindo-se a um funcionário deficiente] tem uma deficiência vocal, se comunica com dificuldade, mas ele é uma pessoa inteligente. (Gestor 1, empresa do segmento editorial)

A afirmação de que a PcD tem uma dificuldade "mas é inteligente" revela, no gestor, uma estrutura discursiva comum nos jargões cotidianos. Ele tenta compensar uma característica considerada ruim com algo que possa ser valorizado. Amaral (1995, p. 116-117) argumenta que tais expressões fazem parte de mecanismos de negação da deficiência, tais como: a) atenuação, que pode ser expressa por frases como "Poderia ser pior" ou "Não é tão grave assim"; b) compensação, onde o 'mas' é a palavra chave: "Deficiente físico, mas tão inteligente"; e c) simulação, expressa em idéias contidas em afirmações como "É cega, mas é como se não fosse".

Deficiência assume, também, na fala dos depoentes, o significado de diferença, ou seja, uma característica específica da pessoa, mas que não pode ser alvo de diferenciação. Esta percepção se aproxima do conceito de diversidade de Thomas Jr. (1996), que a entende como uma mistura de itens caracterizados por diferenças e similaridades. Seria assim um atributo que só se torna alvo de discriminação num ambiente social que desvaloriza a diferença (WOODHANS; DANIELI, 2000). "Deficiência é uma diferença (...) e eu acredito que, por ser diferente, você não pode ser diferenciada" (Pessoa com seqüela de poliomielite, banco privado multinacional).

Emerge nos discursos também a consciência de que, em parte, a percepção da deficiência depende da própria forma como a PcD se vê e se posiciona na arena das relações sociais. Quando se vê como inferior, ou usa a deficiência em causa própria, reforça o estigma que deveria buscar romper:

Aprendi que a deficiência fisica realmente está dentro da cabeça das pessoas. A partir do momento em que você se considera um deficiente fisico e você se utiliza disso para ser menor que os outros ou por beneficio próprio, ai sim você tem uma deficiência. (Pessoa com deficiência no membro superior direito, banco privado multinacional)

Se a deficiência é uma construção social que depende de significados compartilhados, a consciência da PcD em relação à importância de seu posicionamento na construção de um novo sentido para o termo é um fator primordial. Seu comportamento tem um impacto na audiência, uma vez que a atribuição de significados depende de três fatores, como propõe Omote (1996): o ator $(\mathrm{PcD})$, a audiência (pessoas não-deficientes na empresa) e as circunstâncias sob as quais o julgamento ocorre. 


\section{Relações de trabalho no processo de inclusão}

Como se afirmou anteriormente, a inclusão acontece em dois níveis, no individual e no grupal, e se efetiva em cada momento e em cada interação, como mostram Ferdman e Davidson (2002). O que significa que, ao estudar a questão do $\mathrm{PcD}$, é preciso olhar para as dinâmicas dos indivíduos PcDs do grupo no qual estão inseridos e da própria organização como um todo.

A metacategoria 'relações de trabalho' analisa o comportamento inclusivo e a forma como as relações de trabalho se estabelecem entre gestores, PcDs e equipe. Trata de entender os discursos, ações e sentimentos desses atores nas suas relações cotidianas. Divide-se em duas subcategorias: o papel do gestor no processo de inclusão e o papel da PcD no processo de inclusão. Nas linhas discursivas de alguns gestores, este papel aparece vinculado à idéia de compaixão:

O que a gente tenta fazer é atenuar esse problema dentro da empresa, acolhendo essas pessoas, tratando com dignidade, respeito, dando uma responsabilidade para elas sentirem-se úteis também. Eu acho que isso é a coluna vertebral do negócio. (Gestor 1, empresa do segmento editorial)

Nesse caso, a deficiência é um problema a ser atenuado e a função do gestor é a de acolher, receber e fazer a PcD sentir-se útil. Atenuar o problema é uma forma de garantir que o trabalho seja realizado, isto é, que a coluna vertebral do negócio não seja afetada. Isso significa que o papel do gestor é conduzir a presença das PcDs de forma que prejudique o menos possível o andamento do trabalho.

Outra conotação que emerge nos depoimentos é a de que o gestor tem a responsabilidade de garantir produtividade e fazer a PcD prosperar. Para tanto, tem de olhar o processo, motivar, avaliar e dar condições necessárias para que esta se desenvolva, respeitando seu tempo e ritmo próprio. Alguns gestores assinalam que faz parte de sua obrigação disponibilizar meios e recursos apropriados para a evolução na carreira das PcDs.

O papel do gestor no grupo é um papel fundamental, porque o gestor tem que estar preparado para receber as pessoas que têm deficiência. Ele tem que estar consciente de que as pessoas têm ritmos diferentes, estão em momentos de vida diferentes e saber fazer a gestão, olhar o processo. Claro que ele tem que garantir a sua produtividade, o desenvolvimento, desde que o critério dele seja avaliar a capacidade, o desenvolvimento, ter o tempo adequado pra que essa pessoa se desenvolva. O gestor tem uma área de suporte que pode recorrer, mas ele tem autonomia na gestão dessas pessoas. (Gestor 2, empresa do segmento editorial)

[...] Não tem nenhum programa de treinamento especifico. Então, conforme o analista entra, a gente vê qual seria o perfil para ele, de onde ele vem, o que ele já pode ter feito de atividades, o que ficaria mais fácil para ele deslanchar aqui dentro. Então, a gente coloca ele na área que vai 'deslanchar' mais. (Gestor, banco público)

Se considerarmos os contextos de acessibilidade propostos por Sassaki (2006), as falas dos gestores remetem a pelo menos três deles: garantir a comunicação, os instrumentos de trabalho e métodos e técnicas que permitam à $\mathrm{PcD}$ o desenvolvimento de suas potencialidades respeitando suas limitações.

Indo além da questão da acessibilidade, surge no discurso o gestor inclusivo como aquele que assume o papel de professor, dado que, por vezes, as Pcds que ele recebe não têm experiência anterior como funcionários corporativos, e sua escolaridade e qualificação profissional são críticas.

Nós, gestores, temos também que ser professores, porque, como a maioria deles nunca teve uma profissão anterior, a gente tem um desafio muito grande de dar um oficio pra essas pessoas e fazê-las prosperar. (Gestor 1, empresa do segmento editorial) 
O gestor tem o papel de estar motivando, mostrando pra ele que a deficiência não é o problema. $O$ problema é ele saber mostrar para os outros que ele sabe, e todos vão olhar pra ele como sendo uma pessoa que pode querer mais na instituição. (Gestor 2, banco privado multinacional)

A partir dessas análises, é possível afirmar que o papel dos gestores transita entre a função de acolher, minimizar os conflitos e facilitar e promover o desenvolvimento intelectual e profissional da PcD. Neste último caso, vale considerar a importância que alguns gestores apontam em relação à necessidade do diálogo contratual por ocasião da inclusão. Este diálogo assumiu uma dupla função: a de permitir que o gestor conheça o histórico da pessoa deficiente e suas especificidades - o que inclui até a forma de referência à deficiência -, bem como o estabelecimento de acordos mútuos.

A relevância do diálogo vem do fato de que o contexto histórico e o tipo de deficiência vão interferir no processo de inclusão. As experiências de inclusão são tão distintas quanto o histórico e tipo de deficiência dos funcionários. Da mesma forma, há grande diferença entre o universo do indivíduo que não teve nenhuma experiência anterior de trabalho e foi protegido excessivamente pela família daquele que, antes de adquirir a deficiência, já tinha certa experiência e qualificação profissional.

Então foi assim: duas conversas distintas que eu achei até interessantes [...] Um é o primeiro emprego em que a família queria colocar ele numa redoma; e o outro, não: o outro ficou deficiente. Então eu perguntei: "Como foi essa passagem sua? De teoricamente fazer tudo e depois depender dos outros em algum momento?" (Gestor 2, banco privado multinacional)

No caso relatado acima, a primeira $\mathrm{PcD}$ integrada à equipe pertencia a uma família cuja atitude era muito protetora, agravada pelo fato de que se tratava de sua primeira experiência de trabalho, o que fez com que o gestor tivesse de tratar com a família do deficiente também.

A mãe dele veio com ele. Ele veio, ela veio sentar e eu falei: "Eu quero falar com ele sozinho". Ai eu a levei em uma 'salinha', conversei com ele e expliquei que não é porque ele tem essa deficiência que ele vai ser tratado melhor do que os outros ou menosprezado, não. Fiquei conversando com ele mais ou menos duas horas e falei com a mãe dele: "Está vendo esta 'cambada' aí? Vai ser tratado do mesmo jeito que todo mundo, e acho que é isso que ele quer, não é? A partir de amanhã, a senhora não precisa vir mais não. Porque tudo que eu vou tratar é com ele, a senhora tem que deixar ele andar sozinho". (Gestor 2, banco privado multinacional)

[...] Ele [PcD que adquiriu deficiência] teve essa deficiência acho que há uns cinco ou seis anos, passou por momentos dificeis, mas era um 'cara' que já trabalhava. Então, foi mais fácil a conversa. (Gestor 2, banco privado multinacional)

Na relação com a equipe de trabalho se evidencia a importância do gestor na desmistificação de idéias e barreiras preconcebidas.

Teve uma vez que uma funcionária falou assim: "Nossa, mas você deu uma dura neles". Eu respondi: "Ué? Se eu não falar com ele eu vou falar com quem?" Se ele está desenvolvendo o papel errado, porque que eu não vou chamar atenção dele? Eu vou passar os panos quentes? O acionista do banco não quer saber disso, ele só quer o resultado. Eu falei: "[...] Senta no lugar dele que você vai tomar bronca no lugar dele". "Não, não é isso", ela respondeu. Perguntei: "Você acha que eu fui rude?" Ai ela disse: "[...] Eu achava que você poderia ajudar". Eu falei: "Ajudar eu ajudo, eu acho que uma bronca é a melhor coisa". Eu tive um gestor que foi meu pai no banco. Ele sempre falava pra mim: de quem você gosta você cobra mais. Eu não posso falar pra ele: "Olha, meu anjinho, desculpa, você está errado, vamos melhorar aqui assim, assado". Quer dizer, ele pode usar esse argumento para não produzir. Não posso pegar e olhar a deficiência como fator primordial pra que ele não trabalhe, ou que ele possa esconder suas deficiências de trabalho. Eu falei para ela: "Sabe como eu vou falar? Do 
jeito que eu falo com todo mundo: com respeito, mostrando o caminho que tem que ser seguido". Eu achei que isso era o jeito mais certo (Gestor 2, banco privado multinacional)

Foi uma das primeiras coisas que eu falei: 'Não cobrem deles a deficiência, cobrem deles o profissional'. Isso foi [...] dar liberdade para as pessoas para que não coloquem uma barreira (Gestor 2, banco privado multinacional)

Outra subcategoria das relações de trabalho é o papel da $\mathrm{PcD}$ no processo de inclusão. As falas mais uma vez reforçaram que o posicionamento da $\mathrm{PcD}$ com seus pares, em relação à sua deficiência, contribui para $\mathrm{o}$ estabelecimento de novos sentidos para as relações vividas no espaço empresarial. Isso demonstra a necessidade da própria PcD em desmistificar discursos, romper estigmas e propor o estabelecimento de condutas adequadas, que não sejam nem superprotetoras nem limitantes, o que só é possível quando a PcD tem o que Mpofu e Harley (2006) chamam de "identidade saudável da deficiência".

Quando eu cheguei, eles queriam me superproteger, sabe um bibelô de cristal? Aí eu já quebrei isso. Eu falei: "Não! Vamos esquecer que eu tenho deficiência". E esqueceram mesmo, de fato. Porque, depois, eles me pediam as coisas que antes diziam que não podiam me pedir. Quer dizer, eu tirei da mente deles que eu era 'deficiente'. (Pessoa com seqüela de poliomielite, banco privado multinacional)

As pessoas dentro do banco nunca me viram como deficiente físico, justamente pela forma de pensar que eu tenho [deficiência]. Pelo fato de eu brincar com minha própria deficiência, de fazer com que aquilo seja uma coisa normal pra mim, então os meus pares nunca me viram como deficiente físico. Eu nunca tive um tratamento diferenciado por causa disso. Realmente pelo fato de não me ver dessa forma. (Pessoa com deficiência no membro superior direito, banco privado multinacional)

Ainda em relação à equipe, à medida que o processo de inclusão vai se tornando natural, uma parte da cultura da organização, a brincadeira, o humor e a espontaneidade tomam conta do ambiente e permitem que as pessoas se tratem de maneira igualitária, sem tantas reservas, independentemente da existência ou não da deficiência.

Hoje a gente até brinca (...) Não pode ser também muito rígido, ele não pode exigir muito da gente, porque muitas vezes a gente esquece que ele é deficiente. É que nem quando fala para um cego: "Você não enxerga isso?" A gente não fala por mal. A gente fala: "Vamos andando, vamos andando", e ele vem atrás da gente. (Gestor, empresa do segmento de transporte)

\section{Dificuldades do processo de inclusão e estratégias de enfrentamento}

A primeira dificuldade que aparece no discurso gerencial é a de equacionar uma questão que é ao mesmo tempo política, social e profissional:

O que os funcionários têm percebido é que, com o tempo, as questões administrativas e técnicas vão se organizando de um jeito muito próprio. Então, a maior dificuldade que a gente tem hoje é que a própria pessoa com deficiência perceba que ela está aqui para um determinado trabalho e não em luta da causa que ela tem, e, muitas vezes, lutou por vários anos, mas que aquele espaço é um espaço de trabalho produtivo. (Gestor 2, empresa do segmento editorial)

A questão da inclusão de indivíduos em situações de desvantagem na organização faz com que as formas tradicionais de luta tenham de ser traduzidas para uma lógica empresarial. A forma de reivindicar direitos não pode ser a mesma que se estabelece no ambiente fora da organização, nas ruas, nos movimentos sociais. No entanto, para o gestor em questão, a empresa se resume a um espaço de trabalho produtivo, que não deve comportar manifestações alheias ao interesse do negócio.

Neste caso, fica a questão: tem o funcionário o direito de lutar? Certamente que sim, já que as relações na empresa são desiguais. Tem o gestor o direito de dizer que ali é um espaço reservado ao trabalho apenas? $\mathrm{O}$ 
cerne aqui são os ajustes destas questões, que têm de evoluir de maneira positiva e equilibrada para ambos os lados.

Encontrar equilíbrio nos embates cotidianos na organização depende da natureza da dificuldade que se apresenta para gestores e PcDs. Se de um lado encontram-se gestores que, como se viu anteriormente, querem suprimir qualquer natureza reivindicatória do ambiente corporativo, de outro se encontram, também, PcDs que usam sua deficiência para conseguir vantagens adicionais e exigir um tratamento diferenciado injustificado:

Tinha um rapaz que trabalhava antes aqui que achava que devia ser tratado de forma diferenciada. $E$ muito pelo contrário: eu tenho que respeitar as limitações que a deficiência causa ao profissional [...] Ele deixava muito claro que ele se achava diferente dos outros, se achava no direito de ter vantagens que os outros não tinham, e isso causava um mal estar dentro da equipe muito grande. No dia em que ele foi desligado, ele falou: "Eu acho que eu nunca fui tratado aqui como eu deveria, porque eu me sentia menosprezado". Eu respondi: "Como assim 'menosprezado'? Você achava que tinha que ter algum tipo de facilidade. Com exceção do respeito à sua condição de deficiência, você tem que ser tratado como todos os outros". Ele dizia: "Não, eu acho que eu tinha que ter um tratamento diferenciado". (Gestor 1, banco privado multinacional)

Tal relato corrobora o argumento de Goffman (1975) sobre o fato de o indivíduo idealizar uma autoimagem que o leva a exigir dos outros uma determinada forma de tratamento que julga ser seu direito.

Por outro lado, há, por vezes, uma relutância da própria equipe de trabalho por se sentir prejudicada pelo tratamento diferenciado dado ao PcD. O gestor da empresa pública do segmento de transporte relata situações em que a mera modificação do layout é alvo de resistência e atribuição de privilégios aos 'deficientes' por parte de funcionários da corporação.

Em grande parte, essas dificuldades surgem da própria forma como o processo de inclusão é conduzido e do desconhecimento sobre a natureza e especificidade da deficiência. A empresa do mercado editorial, por exemplo, optou por contratar deficientes auditivos sem desenvolver um conhecimento anterior sobre a natureza deste tipo de deficiência, nem mesmo um suporte especializado que pudesse minimizar as barreiras de comunicação. Neste caso, pôde-se observar que as conseqüências de uma inclusão realizada desta forma podem ser desastrosas para a empresa e para a própria PcD.

Eles olham e percebem o ambiente de uma maneira diferente da gente. Quando você está gerindo uma equipe grande, você tem que entrar nos detalhes dessas diferenças e procurar o melhor caminho, e, muitas vezes, o melhor caminho pode ser bom pra um e não pra outro. [...] Essas pessoas foram bem recepcionadas e adotadas (pela equipe de trabalho), mas, pela própria cultura delas, tendem a formar grupos. (Gestor 1, empresa do segmento editorial)

O principal obstáculo que enfrentou o gestor foi o comportamento de isolamento dos deficientes auditivos. Em virtude da dificuldade de comunicação - algumas vezes nem entendido nem se fazendo entender pelos demais - começaram a se isolar em grupos. A falta de comunicação gerou atritos entre os pares na empresa e prejudicou todo o processo de interação.

No início, você tem que ter muita boa vontade, muita paciência. E, com a necessidade, você acaba se comunicando de uma forma ou outra, como um simples bilhete, forma gestual, mímica (muitos deles conseguem ler lábios). Eu não sou conhecedor de libras, até porque eu não tive tempo pra aprender. As pessoas que não são portadoras de deficiência acabam adquirindo, elas acabam sentindo uma necessidade e se especializam, fazem um curso. Na unidade de Itapecerica o processo de inclusão não foi assim. Não que tenha sido dramático, [mas] é uma região muito afastada, tem uma característica mais de interior, então as pessoas foram muito receptivas. Já em Osasco eu tive muitos problemas. Atrito com outros funcionários, com a equipe, aquele clã. [...] Eu percebo, que eles têm uma necessidade, uma vontade de fazer com que uma pessoa entenda o que está sendo falado e essa outra 
pessoa tem que ter vontade de entender. A gente percebe que a comunicação é fundamental. (Gestor 1, empresa do segmento editorial)

É interessante observar que um gestor com $99 \%$ de deficientes auditivos em sua equipe, que se isolam pela dificuldade de comunicação, não faz um curso de libras porque "não tem tempo". Nesse caso, por que a empresa inclui em sua maioria o deficiente auditivo e não disponibiliza um tempo na semana para o aprendizado de libras para seus funcionários? Não por acaso este gestor assim descreve a experiência de inclusão: "não que tenha sido dramático". A expressão parece demonstrar a dificuldade do processo, decorrente especialmente da formação de agrupamentos naturais entre as PcDs, que, segundo o entrevistado, acabaram se tornando um "clã", não entendiam ninguém nem se faziam entender.

A forma de inclusão reforçou o comportamento do endogrupo, como argumentam Ashforth e Mael (1989) e Tajfel (1982). A afiliação a um grupo representa para o indivíduo a possibilidade de reduzir a incerteza subjetiva (HOGG; TERRY, 2000), uma vez que o significado emocional implícito na relação indivíduo/grupo é um estimulo afetivo à medida que a pessoa se sente parte integrante do grupo.

A dificuldade de comunicação, associada à falta de iniciativa da empresa em promover cursos de libras ou mesmo dinâmicas que permitissem a interação, reflete a forma como o processo de inclusão foi, de fato, conduzido. Coloca-se o deficiente auditivo na organização, sem sequer saber como lidar com a situação, como integrá-lo no ambiente. E o gestor se vê diante de uma situação nova para a qual não consegue dar respostas satisfatórias.

O natural num processo efetivamente inclusivo é que, no início, haja apoio de especialistas externos. Com o tempo, os próprios parceiros de trabalho devem incorporar a linguagem, dispensando o especialista, como se vê no exemplo a seguir.

A empresa de transporte público procurou alocar pessoas que dessem suporte à $\mathrm{PcD}$ (tetraplegia total), de forma que esta tivesse um maior grau de autonomia. Antes da existência do Projeto de Inclusão, o profissional de suporte era oferecido por uma associação. Hoje, os colegas de equipe da empresa desempenham esta função, o que mostra a tentativa da empresa em envolver os funcionários no processo, como relata a $\mathrm{PcD}$ tetraplégica:"[...] a autonomia eu fui ganhando quando fui desenvolvendo parceiros no trabalho [...]. Logo no início, [a empresa] não conseguia pôr alguém para me auxiliar".

Diferente é o caso da empresa que contratou pessoas com deficiência auditiva. Não só não há um esforço para que os funcionários se familiarizem com a linguagem dos sinais, como os dois únicos intérpretes da empresa saíram de férias ao mesmo tempo:

O problema é [...] que aqui são vários deficientes auditivos, mas os intérpretes estão de férias. Ai fica dificil. [A empresa] Precisa dos intérpretes. [...] Falar o básico com eles umas dez pessoas conseguem, mas são muitos gestos. (Pessoa com distemia, empresa segmento editorial)

As dificuldades aumentam também conforme o tipo e o grau de deficiência, o que tem impacto direto na progressão da carreira:

Ele entrou no programa de trainee e eu tenho uma dificuldade, um dilema. Se eu não promovê-lo a analista, estarei fechando uma porta. Aqui se entra como analista trainee e vai subindo. O que uma pessoa normal faz num grau 100, ele faz num grau 20. Como vai mensurar isso? Como vai comparar com os outros analistas? Vai fechar a porta? Tem que buscar o ponto certo e isso é difícil de conversar com ele. Ele vai percebendo, e nós também, que, das 15 pessoas que entraram no programa, algumas já foram promovidas e ele está ficando para trás. Ele também cobra "O que vai acontecer comigo?” E eu cobro o pessoal da administração: "O que faço com ele?" Promover por promover não é correto, mas quais são os parâmetros que se vai usar? 'Tenho certeza de que futuramente ele vai ser brecado e como vou tratá-lo? Como ele vai se sentir quando chegar nesse ponto?' É esse o tipo de 
questionamento, são pontos que a direção vai ter que pensar como resolver. (Gestor 2, empresa pública do segmento de transporte)

$\mathrm{O}$ gestor não consegue prover uma resposta eficiente para a questão da $\mathrm{PcD}$ tetraplégica e delega o dilema à direção da empresa. Os parâmetros de avaliação e promoção da PcD utilizados pelo gestor são os mesmos atribuídos às pessoas sem deficiência. Prevalece, assim, a lógica empresarial, quantitativa e comparativa, e não a lógica da diversidade. As especificidades e potencialidades desta $\mathrm{PcD}$ não são objeto de discussão.

Aqui há a necessidade de se rever o significado do desenvolvimento profissional das PcDs, valendo-se de parâmetros inclusivistas, o que significa pensar o indivíduo em relação a ele mesmo, à sua prontidão físicointelectual-social e ao ambiente físico-social em que está inserido.

Em relação ao comportamento da equipe, duas posturas exemplificam as dificuldades do gestor: a do profissional que se recusa a trabalhar com a $\mathrm{PcD}$ e a que desconsidera a possibilidade de esta pessoa ser ativa.

Dentro da empresa, eu já ouvi: "Por que você não deixa ele (PcD) em casa? Por que não coloca na 'salinha' lendo jornal?" Respondi que ele não é um vaso de flor para ser deixado no cantinho. "Se coloca no lugar dele. Como você se sentiria?" São posições que já ouvi na empresa e não são de analistas, são de chefias. Tem pessoas que vieram conversar comigo: "Olha, eu não vou poder conversar com ele, porque eu me sinto meio intimidado, bloqueado [...]" A nossa maior dificuldade foi tratá-lo como uma pessoa igual a nós, porque a primeira impressão que se tinha é que ele seria uma pessoa diferente, que deveria ser tratado como uma pessoa diferente. (Gestor 2, empresa pública do segmento de transporte)

É interessante observar que este preconceito manifesta-se independentemente do grau de qualificação da $\mathrm{PcD}, \mathrm{o}$ que reforça a crença de que a limitação física acarreta um comprometimento intelectual. Conforme destaca Goffman (1988), as pessoas tendem a inferir, baseando-se nas imperfeições originais, uma série de outras imperfeições, o que caracteriza um fenômeno de generalização da deficiência, como se a deficiência tornasse as pessoas totalmente incapacitadas, independente do grau e tipo de comprometimento presentes.

[...] Muitas vezes é engraçado, porque você ouve muita gente falar assim: "Ah, se eu fosse você, eu não tinha pegado, porque será que ele vai conseguir se desenvolver?” Aí, ao mesmo tempo, quando você olha para uma pessoa que fez duas faculdades (ele fez duas faculdades), fez uma pós-graduação em controladoria, você pensa "Será que a pessoa não é capaz de aprender?" Você tem que dar uma chance para a pessoa. (Gestor, banco público)

Do ponto de vista da $\mathrm{PcD}$, muitos são os fatores que dificultam seu real desenvolvimento na organização e sua ascensão profissional. Mesmo os indivíduos que se tornaram deficientes e cujo lastro profissional anterior ao acidente permitiu que se diferenciassem de alguém que está começando a carreira, prevalecem os limites que o impedem de progredir na empresa. No caso da PcD tetraplégica, sua própria condição a impede de participar de treinamentos longos, ou dar respostas muito rápidas. Seu tempo é diferente e a empresa tem de saber se adequar a esta realidade.

Eu tenho que me conformar com algumas coisas. Eu não consigo escrever textos longos, nem com muita velocidade, não consigo dar respostas muito rápidas. Eu tenho um timing diferente [...] Tem situações que eu teria que viajar, participar de fóruns de outras atividades, não dá para eu ir. Eu acho que uma realidade hoje [seria] a empresa pagar para eu ir, pagar mais alguém para estar comigo. Quer dizer, não é realidade isso, acho que isso impede que eu avance, e alguns treinamentos, algumas coisas que aparecem, eu sei que também não são possíveis. Eu não consigo diariamente estar dez horas em função do trabalho. Tenho fisioterapia a fazer [...]. Quinze anos de lesão medular pesam bastante na saúde. [...] Acho que preciso conseguir evoluir por outros caminhos. (Pessoa com tetraplegia, empresa pública do segmento de transporte) 
O aspecto mais grave para determinadas deficiências é o problema da locomoção. O curioso de se observar é que em muitos casos as reuniões e treinamentos não são deslocadas para o andar térreo, onde se encontra o cadeirante, que, simplesmente, fica isolado do processo:

Eu estou em briga na minha agência, porque eu não subo as escadas. Pedi um elevador desde minha entrada e até agora não colocaram [...] as barreiras arquitetônicas é que me podam o acesso ao outro nível da agência, onde eu posso conhecer outros trabalhos da agência. Por falta do elevador, eu fico lá embaixo. (Pessoa com seqüela de poliomielite, banco público)

[...] Entra muito a questão dos elevadores: é raro você encontrar um adaptado, ainda mais com um software de voz que faça o elevador falar em qual andar ele esteja. (Pessoa com deficiência visual, banco privado nacional)

Por vezes, a situação se torna perversa, como se vê no diálogo a seguir. Em protesto à falta de condições de acessibilidade, a $\mathrm{PcD}$ se recusa a subir escadas para participar de reuniões da empresa. Contudo, sarcasticamente, seu colega a provoca em dia de festa, ocasião da qual fez questão de participar.

[...] O chefe falou pra mim: "Mas você não falou que não está subindo mais a escada porque sua coluna não está boa?" Eu falei: "Não, mas é que hoje não é reunião, hoje é dia de festa [...] Você acha que eu vou deixar de comer um pedaço de bolo de chocolate" Ai ele disse: "Ah, mas a gente levaria um pedaço de bolo pra você". (Pessoa com seqüela de poliomielite, banco público)

Uma explicação para a dificuldade de ascensão profissional provém do medo e da descrença na capacidade intelectual da $\mathrm{PcD}$. O estigma da deficiência se sobrepõe à capacidade da $\mathrm{PcD}$, como se pode observar no seguinte depoimento:

[...] Às vezes eu acho que dá um pouco de insegurança nessa hora [da promoção da PcD]. Eles não têm uma adaptação correta para estar promovendo um deficiente, ainda mais no meu caso, que é visual [...] As pessoas, no modo de ver a pessoa portadora de deficiência visual, chegavam a desacreditar, e colocar um pouco de insegurança na hora de oferecer esse serviço ao deficiente [...] Eles acham que a deficiência pode prejudicar um pouco. (Pessoa com deficiência visual, banco privado nacional).

- Estratégias de enfrentamento

Entre as formas de enfrentamento das dificuldades descritas nos depoimentos, destacam-se dois comportamentos característicos.

De um lado, a PcD, que busca 'melhorar o seu trabalho', qualificar-se, mostrar que tem potencial e que se esforça sobremaneira, por vezes superando o ritmo de trabalho da média de seus pares sem deficiência. Goffman (1975) destaca que uma pessoa estigmatizada pode dedicar um grande esforço individual no domínio de atividades consideradas geralmente inapropriadas à sua condição, seja por motivos físicos ou circunstanciais. Na tentativa de romper com a realidade de seus atributos, emprega uma interpretação nãoconvencional do caráter de sua identidade social.

Eu tento me esforçar ao máximo pra me desenvolver. Mas é claro que limitações todo mundo tem, e a gente tem que aprender a lidar com elas. Eu acho que através (sic) do meu trabalho, no dia-a-dia, é a melhor forma de mostrar que você é capaz, que você consegue trabalhar com a sua limitação. (Pessoa sem o braço direito, banco privado nacional).

Por outro lado, há outra estratégia de enfrentamento, que é a da PcD que 'luta na empresa' por condições adequadas ao seu desenvolvimento.

Eu me recuso a subir as escadas para participar de reuniões. Em protesto. [...], eu não subo [referindo-se à falta de um elevador na agência] [...] Como membro da Cipa [Comissão Interna de 
Prevenção de Acidentes], eu vou lutar, vou entrar em contato, vou reclamar. Eu quero marcar uma entrevista com a moça do RH e quero falar sobre esta questão [...], mas eu estou na luta para que esta [barreira] seja derrubada. (Pessoa com seqüela de poliomielite, banco público).

\section{Aprendizagem}

Aprendi que existem necessidades e que são muitas. (Gestor 1, empresa do segmento editorial)

Um dos pontos centrais destacados nos depoimentos como parte do processo de aprendizagem dos gestores é ter de começar a pensar em termos de necessidades das pessoas: do que estes indivíduos precisam e o que o gestor tem de prover para garantir êxito no processo de inclusão. Nesse sentido, reforçam a importância de estabelecer um diálogo com a PcD, aproximar-se do seu universo para que a aprendizagem mútua ocorra.

O que vale nisso é o dia-a-dia, principalmente a conversa. A conversa se abriu e ele também aprendeu a trabalhar isso; é uma coisa bilateral: ele ensina e a gente também ensina. Nós caminhamos e aprendemos juntos. (Gestor 2, empresa pública do setor de transporte)

Observa-se aqui a necessidade de se dar sentido ao processo de inclusão, o que pode remeter ao conceito de sensemaking de Weick (1995), ao identificar sete propriedades típicas de qualquer atividade de criação de sentido: 1) construção de uma identidade; 2) essa construção é sempre retrospectiva; 3) realizada num contexto social; 4) por meio da ação e do discurso performativos, isto é, capaz de criar ambientes sensíveis; 5) reporta-se a eventos em curso; 6) de onde se extraem sinais; 7) guia-se pela plausibilidade e não pela verdade.

De acordo com o autor, as pessoas na organização não apenas interpretam a realidade, mas produzem sentido no ambiente em que estão inseridas, constroem coletivamente significados.

Tudo o que eu sei hoje de crédito e agora que eu estou aprendendo aqui é novo pra mim. Eu estou aprendendo dia a dia. E eu acho que a organização aprendeu com a gente a respeitar, a não segregar, a ver que a gente tem capacidade como uma pessoa que não tem deficiência. [A organização] aprende como lidar com as pessoas. (Pessoa com seqüela de poliomielite, banco privado mutinacional).

Eu percebo que, pelo menos até agora, os meus chefes têm aprendido bastante com isso também. Às vezes eles falam que eu não vou conseguir, mas que não tem problema, que eu posso fazer outra função. E enquanto eles estão falando isso, eu já vou lá e vou fazendo, pra ver se eu vou conseguir [...] Eles deixaram de me ver como um coitado. Eles viram que eu era capaz de fazer aquilo, então eu achei muito legal. (Pessoa sem o braço direito, banco privado nacional).

Se a aprendizagem é bilateral, o indivíduo aprende que é capaz e a organização aprende a respeitar as diferenças, a não discriminar, a extrair o melhor da diversidade.

\section{Conclusão: implicações para a prática da inclusão}

Com a intenção de entender as experiências de inclusão de gestores e PcDs e identificar qual o significado da inclusão, conduziu-se um estudo qualitativo interpretativo em cinco empresas paulistas. $\mathrm{O}$ estudo teve por intenção dar duas contribuições: entender o significado da inclusão em empresas que têm uma política de diversidade e discutir quais as implicações dos resultados para a prática inclusiva. A seguir, apresenta-se um quadro-síntese que resume as implicações da inclusão, construído com base nos relatos das experiências estudadas: 
Quadro 3 - Resumo das implicações da inclusão.

\begin{tabular}{lll}
\hline Implicações para as PcDs & Implicações para os gestores & Implicações para as empresas \\
\hline Aprender a se posicionar perante & Promover aprendizagem & Criar uma cultura inclusiva \\
seus pares e chefes & compartilhada & Estudar/conhecer a deficiência \\
$\begin{array}{l}\text { Desenvolver sua capacidade de } \\
\text { trabalho, o saber }\end{array}$ & $\begin{array}{l}\text { Distinguir problemas reais de abuso } \\
\text { da PcD de sua condição }\end{array}$ & $\begin{array}{l}\text { Garantir apoio de especialistas } \\
\text { Quebrar estigmas, romper barreiras }\end{array}$ \\
Traduzir ações reivindicatórias dos & Desenvolver a capacidade de & $\begin{array}{l}\text { Rever ritmo, tempo, horário de } \\
\text { trabalho e sistemas de avaliação }\end{array}$ \\
movimentos sociais em estratégias & trabalho da PcD & convencionais \\
empresariais de luta por direitos & Promover a integração na equipe & Colocar foco no empoderamento da \\
Quebrar estigmas, romper barreiras & Evitar a superproteção & PcD e em suas possibilidades de \\
Expressar claramente suas & Manter sempre o diálogo & ascensão profissional \\
necessidades & Quebrar estigmas, romper barreiras & Garantir todos os parâmetros de \\
& Estudar/conhecer a deficiência & acessibilidade \\
& Colocar foco no empoderamento da & \\
& PcD e em suas possibilidades de & \\
& ascensão profissional & \\
\hline
\end{tabular}

Fonte: as autoras.

Repensar as relações de trabalho baseando-se na presença de atores antes excluídos do cenário empresarial implica discutir os papéis que desempenham gestores e PcDs no processo: significa romper com o olhar convencional dos gestores e educar este olhar para as necessidades das pessoas, com a intenção de extrair a potencialidade dos sujeitos frente aos limites da deficiência.

Uma gestão que se ocupa das 'necessidades das pessoas' busca, sobretudo, a adaptação da organização às PcDs, e não o contrário. Isso pressupõe desenvolver um ambiente propício à igualdade e à plena participação. Participação entendida aqui como a possibilidade de a PcD se manifestar quando assim o desejar, o que demonstra que interessa ao grupo sua participação. Sem participação plena nas atividades não se pode falar em empresa inclusiva.

Para que se atinja este estágio de inclusão é preciso que a diversidade seja potencializada. Dessa forma, a experiência de inclusão tem de ser coletiva, não pode estar concentrada só em uma parte da empresa, tem de estar espalhada na organização. Todos no grupo organizacional têm de ter a sensação de inclusão.

Olhar para as necessidades das PcDs quer dizer garantir o êxito da inclusão, ou seja, o seu desenvolvimento, o que exige que se derrubem barreiras arquitetônicas e atitudinais. Para tanto, é preciso que ocorram mudanças não apenas de cunho organizacional, mas também daquelas que dependem da decisão e da postura dos gestores.

Uma política de inclusão empresarial adequada e forte e exemplos de casos bem sucedidos propiciam o desenvolvimento de uma cultura organizacional inclusiva e flexível o suficiente para responder aos desafios de cada caso. Conhecer a deficiência, dialogar com entidades de apoio e se valer dos conhecimentos já construídos sobre limites e potencialidades das PcDs ao longo dos anos por instituições de apoio são práticas fundamentais àqueles que desejam que suas ações inclusivas prosperem.

Não basta apenas entender de diversidade: é preciso usar a diversidade numa orientação para a aprendizagem e efetividade. Não se trata de tolerar a PcD, o que é insuficiente: é preciso dar oportunidades iguais. Nesse caso, cabe ao gestor e à empresa assegurar políticas e procedimentos que dêem conta de todos os componentes da inclusão, como bem colocam Ferdman e Davidson (2002): presença e visibilidade em grupo e individualmente; segurança (confiança de que não será agredida); eqüidade (tratamento igual); sentimento de valorização individual e no grupo; possibilidade de expressar-se de forma autêntica; voz e participação; sentimento de propriedade; adaptação e aprendizagem contínua, individual e coletivamente; entre outras ações possíveis. 
Voltando ao problema de pesquisa: o discurso e a prática da inclusão nas organizações conciliam o respeito à diferença com igualdade de oportunidades? Na percepção dos entrevistados, os relatos mostram que nem sempre. Embora o discurso tenha amadurecido nesta direção e algumas práticas já revelem avanços consideráveis, como se pôde constatar na pesquisa, as experiências ainda refletem muito mais o paradigma de suporte e serviços do que o paradigma de empoderamento, reflexo direto do significado e da idéia de inclusão. Ainda será necessário muito tempo para que se encontrem formas que levem a que as PcDs se sintam seguras, aceitas, engajadas e respeitadas em seu ambiente de trabalho. 


\section{Referências}

AMARAL, L. A. Conhecendo a deficiência. São Paulo: Robe Editorial, 1995.

ARANHA, M. S. F. Paradigmas da relação da sociedade com as pessoas com deficiência. Revista do Ministério Público do Trabalho, Ano XI, n. 21, p.160-173, mar. 2001.

ARONSON, E.; WILSON, T. D.; AKERT, R. M. Psicologia social. 3.ed. Rio de Janeiro: LTC - Livros Técnicos e Científicos, 2002.

ASHFORTH, B. E.; MAEL, F. Social identity theory and the organization. Academy of Management Review, v. 14, n. 1, 1989.

BATISTA, C. A. M. Inclusão: construção da diversidade. Belo Horizonte: Armazém das Idéias, 2004.

BERGER, P.; LUCKMANN, T. A construção social da realidade. 23.ed. Petrópolis: Vozes, 2003.

BRYMAN, A. Interviewing in qualitative research. In: Social research methods. Oxford: Oxford University Press, 2004.

CAELLI, K.; RAY, L., \& MILL, J. 'Clear as mud': Toward greater clarity in generic qualitative research. International Journal of Qualitative Methods, 2003. Article 1. Retrieved. Disponivel em: <http://www.ualberta.ca/ iiqm/backissues/2_2/html/caellietal.htm>. Acesso em: 15 jan. 2006.

CARVALHO-FREITAS, M. N.; MARQUES A. L. Construção e validação de instrumentos de avaliação da gestão da diversidade: a inserção no trabalho de pessoas com deficiência. In: ENCONTRO NACIONAL DE PÓS-GRADUAÇÃO E PESOUISA EM ADMINISTRAÇÃO - EnANPAD. Anais... XXX, Salvador, 2006.

CARVALHO-FREITAS, M. N.; MARQUES, A. L.; SCHERER, F. L. Inclusão no mercado de trabalho: um estudo com pessoas portadoras de deficiência. In: ENCONTRO NACIONAL DE PÓS-GRADUAÇÃO E PESOUISA EM ADMINISTRAÇÃO - EnANPAD. Anais XXVIII, Curitiba, 2004.

CHAMBON, A. Life history as a dialogical activity: "if you ask me the right questions, I could tell you". Current Sociology, v. 43, n. 2/3, 1995.

COSTA, S. G.; FERREIRA, C. S. Diversidade e minorias nos estudos organizacionais brasileiros: presença e lacunas na última década. In: ENCONTRO NACIONAL DE ESTUDOS ORGANIZACIONAIS - EnEO. Anais... IV, Porto Alegre, 2006.

COX, T. JR. The multicultural organization. The Executive, v. 5, n. 2, May 1991.

CROCHÍK, J. L. Preconceito, indivíduo e cultura. São Paulo: Robe, 1995.

D'AMARAL, M. T. 0 deficiente hoje. In: IBDD - Instituto Brasileiro de Defesa dos Direitos da Pessoa Portadora de Deficiência. Responsabilidade social e diversidade: deficiência, trabalho e exclusão. Rio de Janeiro: BNDES, 2004.

DASS, P.; PARKER, B. Strategies for managing human resource diversity: from resistance to learning. Academy of Management Executive, V. 13, n.2, 1999.

FERREIRA, A. B. H. Novo Aurélio. Rio de Janeiro: Nova Fronteira, 1999.

FERDMAN, B. M.; DAVIDSON, M. N. A matter of difference: inclusion what can I and my organization do about it? Industrial Organizational Psychologist - TIP, v. 39, n. 4, April, 2002.

FLEURY, M. T. L. Gerenciando a diversidade cultural: experiências de empresas brasileiras. Revista de Administração de Empresas, v. 40, n. 3, p. 18-25, 2000.

FLORES, J. Aproximación interpretativa al contenido de la información textual. In: Analisis de datos cualitativos - aplicaciones a la investigación educativa. Barcelona: PPU, 1994.

FREEDMAN, S. M.; KELLER, R. T. The handicapped in the workforce. Academy of Management Review, v. 6, n. 3, 1981.

GEPHART, R. P. JR. From the editors - Qualitative Research and the Academy of Management Journal. Academy of Management Journal, v. 47, n. $4,2004$. 
GLASTRA, F. et al. Broadening the scope of diversity management. Industrial Relations, v. 55, n. 4, p.698-724, 2000.

GOFFMAN, E. A representação do eu na vida cotidiana. Petrópolis: Editora Vozes, 1975.

Estigma. Notas sobre a manipulação da identidade deteriorada. 4. ed. Rio de Janeiro: LTC, 1988.

HANASHIRO, D. M. M. Convivendo com a diversidade cultural. In: HANASHIRO, D. M. M.; TEIXEIRA, M. L. M.; ZACARELLI, L. M. (Org.) Gestão do fator humano - uma visão baseada em stakeholders. São Paulo: Saraiva, 2007.

HEINSKI, R. M. M. Um Estudo sobre a Inclusão da Pessoa Portadora de Deficiência no Mercado de Trabalho. In: ENCONTRO NACIONAL DE PÓS-GRADUAÇÃO E PESQUISA EM ADMINISTRAÇÃO - EnANPAD. Anais... XXVIIII, Curitiba, 2004.

HOOG, M. A; TERRY, D. J. Social identity and self-categorization processes in organizational contexts. Academy of Management Review, v. 25, n. 1, jan. 2000.

JAIME, L. R.; CARMO, J. C. A inserção da pessoa com deficiência no mundo do trabalho - o resgate de um direito de cidadania. São Paulo: Ed. dos Autores, 2005.

KAHNWEILER, M. W.; RIORDAN, J. R. Job and employee support groups: past and prologue. The Career Development Quarterly, v. 47, 1998.

LINCOLN, Y; GUBA, E. Paradigmatic controversies, contradictions, and emerging confluences. In: DEZIN, N. K. e LINCOLN, Y. Handbook of qualitative research. Thousand Oaks, CA: Sage, 2000.

MASON, J. Qualitative interviewing. Qualitative researching. London: Sage, 2002.

MERRIAM., S. B. Qualitative research and case study applications in education. San Francisco: Jossey-Bass Publishers, 1988.

Qualitative research in practice: examples for discussion and analysis. New York: Jossey-Bass, 2002

NERI, M. et al., Retratos da deficiência no Brasil. Rio de Janeiro: FGV/IBRE, CPS, 2003.

NKOMO, S. M.; COX JR., T. Diversidade e identidade nas organizações. In: CLEGG, S. R. et al. (Org.), Handbook de estudos organizacionais. São Paulo: Atlas, 1999.

MPOFU, E.; HARLEY, D.A. Racial and disability identity: implications for the career counseling of African Americans with disabilities. Rehabilitation Counseling Bulletin, v. 50, n. 1, 2006.

OMOTE, S. Perspectivas na conceituação da deficiência. Revista Brasileira de Educação Especial, v. 2, 1996.

PFEFFER, J. Organizational Demography: implications for management. California Management Review, v. 37, n. 1, Fall, 1985.

QUINTÃO, D. T. R. Algumas reflexões sobre a pessoa portadora de deficiência e sua relação com o social. Psicologia \& Sociedade, v. 17, n. 1, jan./abr. 2005.

SASSAKI, R. K. Inclusão - construindo uma sociedade para todos. 7. ed. Rio de Janeiro: WVA, 2006.

TAJFEL, H. Social psychology of intergroups relations. Annual Review of Psychology, v. 33, 1982.

TANAKA, E. D. O.; MANZINI, E. J. 0 que os empregadores pensam sobre o trabalho da pessoa com deficiência? Revista Brasileira de Educação Especial. v.11, n.2, Marília, mai/ago, 2005.

THOMAS JR, R. Roosevelt. Redefining diversity. New York: Amacom, 1996.

THOMAS, D. A.; ELY, R. J. Making differences matter: a new paradigm for managering diversity. Harvard Business Review, Sep./Oct., 1996. TORRES, C. V.; PÉREZ-NEBRA, A. R. Diversidade cultural no contexto organizacional. In: ZANELLI, J. C.; BORGES-ANDRADE, J. E.; BASTOS, A. V. B. Psicologia, organizações e trabalho no Brasil. Porto Alegre: Artmed, 2004.

WEICK, K. E. Sensemaking in organizations. London: Sage Publications, 1995.

WOODHAMS, C.; DANIELI, A. Disability and diversity - a difference too far? Personnel Review, v. 29, n. 3, 2000. 